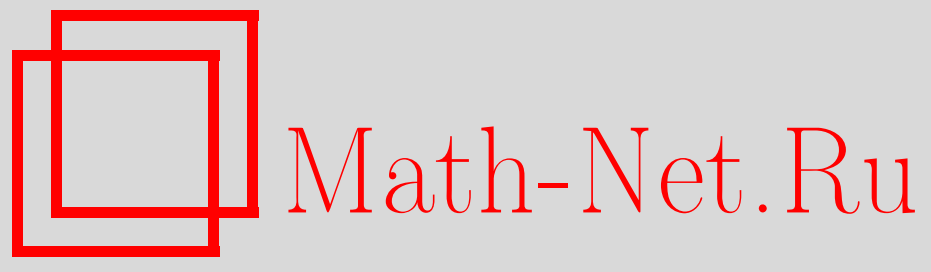

А. Г. Сергеев, О Европейском математическом обществе, УМН, 2016, том 71, выпуск 1, 187-191

DOI: https://doi.org/10.4213/rm9701

Использование Общероссийского математического портала Math-Net.Ru подразумевает, что вы прочитали и согласны с пользовательским соглашением http://www . mathnet.ru/rus/agreement

Параметры загрузки:

IP: 34.229 .108 .108

26 апреля 2023 г., 14:05:24

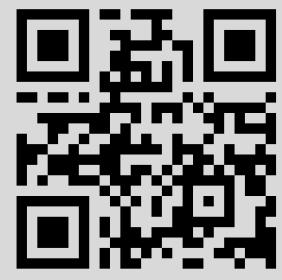




\section{О Европейском математическом обществе}

27-29 ноября 2015 г. в Математическом институте им. В. А. Стеклова Российской академии наук прошло заседание Исполнительного комитета Европейского математического общества. Это является хорошим поводом для того, чтобы напомнить нашим читателям о том, что такое Европейское математическое общество, каковы его цели и ближайшие перспективы.

\section{Создание Европейского математического общества}

Европейское математическое общество (ЕМО) (английский вариант: European Mathematical Society, EMS) было основано в 1990 г. по инициативе Европейского математического совета (European Mathematical Council), который возглавлял в то время Майкл Атья. Произошло это в резиденции Польской академии наук в небольшом городке Мадралин в 20 км от Варшавы. В первоначальный состав ЕМО вошли 27 математических обществ европейских стран, Россия была представлена в нем Московским математическим обществом. Первым президентом ЕМО был избран Фридрих Хирцебрух, юридическим местом пребывания Общества стала столица Финляндии, город Хельсинки. Был утвержден состав Исполнительного комитета Общества:

1. Фридрих Хирцебрух (президент),

2. Алессандро Фига-Таламанка (вице-президент),

3. Чеслав Олех (вице-президент),

4. Крис Лэнс (секретарь),

5. Аатос Лахтинен (казначей),

6. Ева Байер,

7. Алоис Куфнер,

8. Пьер-Луи Лионс,

9. Ласло Марки,

10. Антонио Сент-Обэн.

Было также принято решение о проведении первого Европейского математического конгресса в Париже в 1992 г.

\section{Структура Европейского математического общества}

В настоящий момент Европейское математическое общество объединяет 60 математических обществ европейских стран, 40 математических исследовательских центров и 3000 индивидуальных членов. Россию представляют, помимо Московского математического общества, также Санкт-Петербургское математическое общество и Международный математический институт имени Л. Эйлера.

DOI: $10.4213 / \mathrm{rm} 9701$ 
Высшим управляющим органом ЕМО является его Съезд (Council), в работе которого участвуют делегаты от всех национальных математических обществ, представленных в ЕМО. Съезд собирается каждые два года. В промежутках между съездами главным представительным органом ЕМО становится Исполнительный комитет (Executive Committee), возглавляемый президентом EMO. Президент ЕМО избирается сроком на четыре года без права продления. В состав Исполкома помимо президента входят два вице-президента, секретарь и казначей. Число членов Исполкома не должно превышать 10.

Председателем нынешнего состава Исполкома является президент ЕМО Павел Экснер (Чехия). Кроме того, его членами на сегодняшний день являются:

Франко Брецци (Италия) - вице-президент,

Мартин Рауссен (Дания) - вице-президент,

Шурд Верден Люнель (Бельгия) - секретарь,

Матс Гилленберг (Финляндия) - казначей,

Лоранс Гальперн (Франция),

Герд-Мартин Греель (Германия),

Армен Сергеев (Россия),

Алиса Фиаловски (Венгрия),

Фолькер Мерман (Германия).

Приведем несколько выдержек из официального документа Европейского математического общества, определяющего его статус.

1. ЕМО является ассоциацией, действующей в соответствии с финскими законами. Штаб-квартирой ассоциации является столица Финляндии, г. Хельсинки.

2. Целью ЕМО является поддержка математических исследований в странах Европы с упором на направлениях, находящихся на высоком международном уровне. Особое внимание Общество будет уделять тем видам деятельности, которые выходят за рамки национальных границ, и не вмешивается в вопросы, входящие в компетенцию национальных обществ.

3. Членами Общества могут быть как корпоративные организации, так и отдельные математики. Корпоративные организации, имеющие легальный статус, могут входить в ЕМО в качестве полноправных, ассоциированных и институциональных членов. Полноправными членами могут быть общества, главной целью которых является поддержка исследований в области чистой и прикладной математики внутри Европы. В качестве ассоциированных членов могут выступать любые европейские общества, проявляющие значительный интерес к математическим исследованиям любого рода. Наконец, институциональными членами Общества могут быть коммерческие организации, индустриальные лаборатории или академические институты. В качестве индивидуальных членов могут выступать отдельные математики, как входящие, так и не входящие в состав корпоративных членов Общества.

4. Высшим органом ЕМО является Съезд (Council), который собирается раз в два года. Он решает вопросы о приеме новых членов Общества, избирает президента, вице-президентов и других членов Исполкома ЕМО.

5. Главным органом Общества в промежутках между Съездами является Исполком ЕMO, который проводит в жизнь решения Съезда, отвечает за расходование финансовых средств, назначает представителей и докладчиков от ЕMO на различных 
математических конгрессах и конференциях, осуществляет контроль за деятельностью других комитетов ЕМО.

Европейское математическое общество является аффилированным членом Международного математического союза (IMU) и ассоциированным членом Международного совета индустриальной и прикладной математики (ICIAM).

Издательство Европейского математического общества (EMS Publishing House) публикует большое количество книг по математике и ее приложениям, а также целый ряд известных журналов, таких как "Журнал Европейского математического общества" ("Journal of the European Mathematical Society"), "Анналы Института Пуанкаpe" ("Annales de l'Institut Henri Poincaré"), "Швейцарские математические заметки" ("Commentarii Mathematici Helvetici") и другие. Широко известен публикуемый Издательством журнал общего профиля "Новости EMO" ("EMS Newsletter"), из которого можно почерпнуть информацию о всех важнейших событиях в области математики в Европе.

\section{Комитеты Европейского математического общества}

В состав Европейского математического общества помимо Исполнительного комитета входят еще 11 комитетов, занимающихся отдельными аспектами европейской математической политики.

1. Комитет по прикладной математике (Applied Mathematics Committee). Председатель комитета: Хосе Антонио Карильо; ответственный от Исполкома: Фолькер Мерман. В составе комитета 18 членов.

2. Комитет по развивающимся странам (Committee for Developing Countries). Председатель комитета: Джулия ди Нунно; ответственный от Исполкома: Алиса Фиаловски. В составе комитета 10 членов.

3. Комитет по образованию (Education Committee). Председатель комитета: Гюнтер Тернер; ответственный от Исполкома: Франко Брецци. В составе комитета 17 членов, в том числе один представитель России: Иван Ященко.

4. Комитет по электронным публикачиям (Electronic Publishing Committee). Председатель комитета: Иржи Ракосник; ответственный от Исполкома: Герд-Мартин Греель. В составе комитета 11 членов, в том числе один представитель России: Сабир Гусейн-Заде.

5. Комитет по европейским исследовательским математическим иентрам (ERCOM Committee). Председатель комитета: Арий Лаптев; ответственный от Исполкома: Павел Экснер. В состав комитета входят также директора всех институтов, имеющих статус европейских исследовательских центров по математике.

6. Комитет nо этике (Ethics Committee). Председатель комитета: Адольфо Кирос; ответственный от Исполкома: Франко Брецци. В составе комитета 9 членов, в том числе один представитель России: Татьяна Шапошникова.

7. Комитет по европейской солидарности (Committee for European Solidarity). Председатель комитета: Карлос Касакуберта; ответственный от Исполкома: Армен Сергеев. В составе комитета 11 членов, в том числе, помимо ответственного от Исполкома, еще два представителя России: Игорь Кричевер и Юлий Ильяшенко. 
8. Kомитет по совещаниям (Meetings Committee). Председатель комитета: Нильс Денкер; ответственный от Исполкома: Лоранс Гальперн. В составе комитета 14 членов, в том числе два представителя России: Александр Буфетов и Стефан Немировский.

9. Комитет по публикациям (Publications Committee). Председатель комитета: Бернар Тесье; ответственный от Исполкома: Матс Гилленберг. В составе комитета 9 членов.

10. Комитет по рапространению математики в обществе (Committee for Raising Public Awareness of Mathematics). Председатель комитета: Роберто Наталини; ответственный от Исполкома: Мартин Рауссен. В составе комитета 14 членов.

11. Женский комитет (Committee for Women in Mathematics). Председатель комитета: Беатрис Пеллони; ответственный от Исполкома: Шурд Верден Люнель. В составе комитета 8 членов.

\section{Президенты Европейского математического общества и российские члены Исполкома}

Президент Европейского математического общества избирается Съездом ЕМО сроком на четыре года без права продления. В разные годы президентами ЕМО были:

1. Фридрих Хирцебрух (1990-1994),

2. Жан-Пьер Бургиньон (1995-1998),

3. Рольф Йельч (1999-2002),

4. Джон Кингман (2003-2006),

5. Арий Лаптев (2007-2010),

6. Марта Сан-Соле (2011-2014).

В настоящее время президентом Европейского математического общества является Павел Экснер, избранный на Съезде ЕМО в Сан-Себастьяне в июне 2014 г.

В разные годы в состав Исполкома ЕМО входили следующие представители России:

1. Всеволод Солонников (1993-1996),

2. Анатолий Вершик (1997-2000),

3. Виктор Бухштабер (2001-2008),

4. Игорь Кричевер (2009-2010).

С 2013 г. членом Исполкома является Армен Сергеев.

\section{Европейские математические конгрессы и премии молодым математикам}

Одной из задач Исполкома ЕМО является содействие в организации и осуществление контроля за подготовкой Европейских математических конгрессов, которые собираются раз в четыре года. Предыдущие Европейские математические конгрессы проходили в следующих европейских городах:

1. Париж (1992),

2. Будапешт (1996),

3. Барселона (2000),

4. Стокгольм (2004),

5. Амстердам (2008),

6. Краков (2012).

Следующий Европейский математический конгресс состоится в Берлине с 18 по 22 июля 2016 г. 
На каждом Европейском математическом конгрессе присуждаются 10 премий ЕМО для молодых математиков возрастом не старше 35 лет. Из российских математиков такие премии получали:

1. Александр Гончаров (1992);

2. Максим Концевич (1992);

3. Дмитрий Крамков (1996);

4. Григорий Перельман (1996);

5. Леонид Полтерович, также представлявший Израиль (1996);

6. Стефан Немировский (2000);

7. Андрей Окуньков (2004);

8. Станислав Смирнов (2004);

9. Алексей Бородин (2008);

10. Александр Кузнецов (2008);

11. Ольга Хольц (2008).

Максим Концевич, Григорий Перельман, Андрей Окуньков и Станислав Смирнов были впоследствии удостоены Филдсовских медалей.

\section{Заседание Исполкома Европейского математического общества в Москве}

В этом году Исполком Европейского математического общества впервые провел свое заседание в Москве. Ранее на территории России Исполком ЕМО собирался в Санкт-Петербурге во время математического фестиваля (9-12 июня 2007 г.), посвященного 300-летию Эйлера.

С 27 по 29 ноября члены Исполкома обсуждали разнообразные проблемы, связанные с деятельностью ЕМО, в том числе касающиеся проведения ближайшего Съезда EMO и Европейского математического конгресса в Берлине в июле 2016 года.

В рамках заседания были также представлены информационные сообщения о Московском математическом обществе (докладчик: президент ММО Виктор Васильев) и Математическом институте им. В.А. Стеклова РАН (докладчик: заместитель директора МИАН Дмитрий Орлов). Видеозапись этих выступлений размещена на вебсайте Математического института им. В. А. Стеклова: www.mi.ras.ru. 